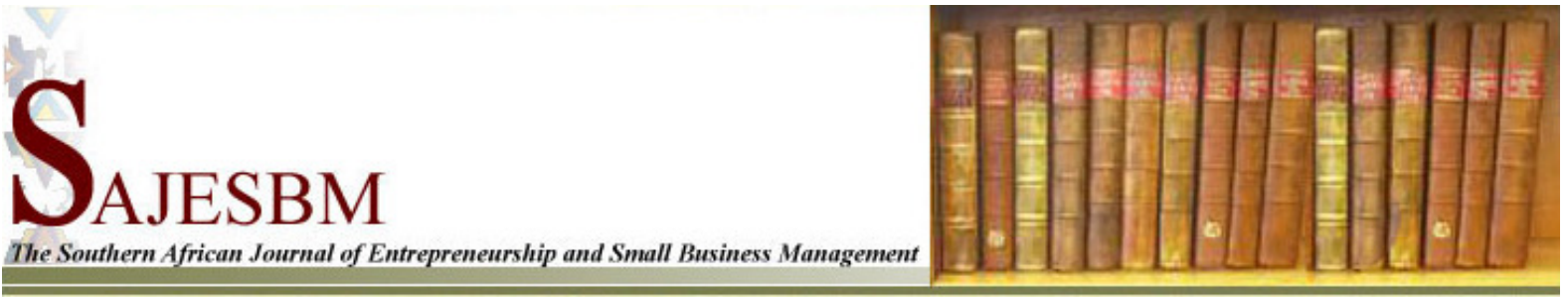

\title{
Entrepreneurship in motion: Towards an interdisciplinary and an eclectic perspective
}

\author{
Darma MAHADEA \\ School of Accounting, Economics and Finance, \\ UKZN (PMB Campus) \\ E-mail: Mahadead@ukzn.ac.za
}

\begin{abstract}
During the past two decades there has been a heightened policy and research interest in the entrepreneur and entrepreneurship in South Africa and other countries. The recent focus on entrepreneurship has made an understanding that the nature or role of entrepreneurs is essential for economic growth and business development. Without entrepreneurs, there cannot be any entrepreneurship, whether in a large or small venture. It is increasingly realized that SMME entrepreneurs and entrepreneurship are critical to the generation of output growth, employment creation, wealth expansion, revenue generation and poverty alleviation for individual and national prosperity, when many large firms are downsizing and retrenching labour, amidst a background of recessionary circumstances and fiscal stress. Entrepreneurship has been conceptualized by different schools of thought, stressing different functions, under diverse circumstances in different historical times. This paper critically examines the nature of entrepreneurship by selectively drawing from the economic, management and psychological schools. It then presents an eclectic view of entrepreneurship related to decision-making ability under conditions of uncertainty by individuals who have access to and can control the utilization of resources in response to opportunities. The paper offers some pointers for enhancing the supply of effective entrepreneurship at the national level in South Africa, and suggests that an interdisciplinary approach is needed to gain a better understanding of entrepreneurship.
\end{abstract}

\section{INTRODUCTION}

Although entrepreneurship has always been an integral facet to human and business development (Urban, 2008: 27) it has been the focus of heightened interest in the policy and academic circles in the past two decades. Against a backdrop of the recent global recession, downsizing by large firms and problems of rising inequality, unemployment and budget deficits in Europe, South Africa and many developing countries, it is realized that vigorous entrepreneurship is critical for sustainable job creation and economic growth in a society. Entrepreneurship is becoming one of the popular undergraduate and post-graduate courses within economics and management at universities and institutions of higher learning in South Africa and other countries too.

In the economic framework, entrepreneurship is regarded as a prime factor of production that coordinates other inputs and organizes production in the enterprise. Social scientists 
since the days of Adam Smith and Alfred Marshall have identified risk-taking as fundamental to the practice of entrepreneurship. Others have conceived the entrepreneurial function as managing uncertainty, innovating and exploiting disequilibrium. Theodore Schultz (1980), a Nobel Prize-winning economist, regarded entrepreneurship as the ability to reallocate and adjust resources in response to changing circumstances. Accordingly, stimulating entrepreneurial ability is necessary to sustain country's economic growth (Schultz, 1980). Until recently, developing countries placed considerable efforts on physical capitalinvestment, in their quest for economic expansion, and entrepreneurship was regarded as a residual factor in the neoclassical growth model. However, recently entrepreneurship gained eminence in the endogenous theory, as it is regarded as the engine of growth and development in an economy (Lucas, 2009). Thus, presently the economics of entrepreneurship is a thriving research field (Parker, 2009).

Further, Keynesian policies, in support of an expansionary state allocation of resources, were previously considered necessary for creating and sustaining growth and employment in the economy. However, while government intervention may be beneficial, it also entails costs that can mitigate against the delivery of prosperity to all in the so-called South African rainbow society. Indeed, scholars who subscribe to Hayekian views of the Austrian School, argue that government meddling in the economy inevitably leads to state control over nearly all aspects of society, possibly tending to a switching off or discouragement of entrepreneurial opportunities (Kirzner, 2009). Others argue that government is not only just inefficient and expensive, but it creates a culture of impunity and dependency that stunts free will and entrepreneurship (Ramphele, 2012).

Despite the frequency with which the term entrepreneurship or entrepreneur is used, there is a lack of consensus on the fundamental attributes underpinning this factor. This is partly because of the complexity and richness of entrepreneurship as a creative phenomenon. While entrepreneurship has its roots in Economics, the entrepreneur tends to be an enigmatic factor and it is one of the most intriguing and elusive characters in economic analysis and in the theory of the firm (Baumol, 1968; Foss and Klien, 2012). Economists still debate what constitutes entrepreneurship (Storey and Green, 2010).

Entrepreneurial activity might be conceived of as the dynamic process of business creation and wealth generation in response to perceived opportunities, with the main agent in this process being the entrepreneur. Stevenson and Jarillo (1990: 23) consider entrepreneurship as an approach to management, defining it as a process by which individuals, individually or jointly pursue opportunities, without regard to the resources they currently control. In literature, entrepreneurship is also associated with business ownership and self-employment in small and medium-sized enterprises, SMEs (Wenneckers and Thurik, 1999; Bridge, O'Neill and Martin, 2009). Certain traits are required for individuals to take up the entrepreneurial route and to be successful in that role, such as innovative ability, risk-taking propensity, commitment and the need to achieve, locus of control and leadership capabilities (Deakins and Freel, 2012). One then needs to draw from the psychological school to gain a better understanding of effective entrepreneurship.

The search for a proper understanding of entrepreneurship thus interfaces with different disciplines. As Baumol (2012) argues, no single disciplinary framework can explain the entirety of the entrepreneurial phenomena.

Accordingly, this paper examines the essence of entrepreneurship from an interdisciplinary perspective, on the basis of which an eclectic paradigm is presented. The paper highlights the conceptualization of entrepreneurship and attributes of the successful entrepreneur by selectively drawing from the economic, managerial and psychological schools respectively. These are covered in the next three sections. Against this background, an eclectic view of 
entrepreneurship is developed by integrating the different approaches. This is followed by a conclusion, offering directions for an enhanced understanding of the conceptualization and development of entrepreneurship.

\section{SOME ENTREPRENEURSHIP IDEAS FROM THE CLASSICAL ECONOMIC SCHOOL}

According to Cantillon, who first introduced entrepreneurship into the economic literature in 1734 in his "Essai sur la nature de commerce en general', the entrepreneur is 'a go between', an intermediary or broker. He coordinated the production process, conducts all exchanges and bears risks as a result of buying at certain prices and selling at uncertain ones, when costs may be known but rewards are uncertain. To J. B. Say (1803), a French economist, the entrepreneur is an organizer of production, mediating between various service providers and consumers (Bridge et al, 2009). For the effective exercise of his function, Say's entrepreneur must possess a combination of moral qualities, judgment, perseverance, knowledge of business and the 'art of super-intendance and administration'. Without these entrepreneurial talents, the success of a business is doubtful.

To Adam Smith, the entrepreneur is the classical owner-manager capitalist who risks his wealth in establishing a business. In the neo-classical economic school, the entrepreneur assumed a shadowy role once the optimal factor combination that maximizes profits or minimises costs has been arrived at. Operating under conditions of perfect competition, the management of the firm simply replicates the optimizing processes that maximize return, leaving hardly any dynamic role for the entrepreneur (Casson, 2003).

Marshall's (1920) view of entrepreneurship is somewhat similar to that of Say. He observed that the activities involved in undertaking a business are different from those of superintending a going concern. Part of the superintendence or control functions can be delegated to salaried managers. In the exercise of his entrepreneurial functions, as an employer, the business individual must be a 'natural leader of men' (Marshall, 1920: 248). In the case of a small firm, the founding entrepreneur may undertake almost all the business risks; but in the context of a joint-stock company, the risk-bearers are the shareholders. As the small firm grows, the entrepreneur must grow in his capacities to manage that growth. Further, if he is to continue to be successful, he must retain his versatility, perseverance, tact, power of initiation and must rely on his own judgment as to what are likely to be the coming relations of demand and supply (Marshall, 1920: 238).

The Knightian entrepreneur is a person who is prepared to undertake an uninsurable risk by starting up his own business, and in return, if successful, he receives an uncertain income (profit) as a reward for bearing this uncertainty. The function of a manager does not in itself imply entrepreneurship, but a manager becomes an entrepreneur when his performance requires that he exercise judgment involving liability to error (Knight, 1921:276). The entrepreneur makes judgments about an uncertain future and in this regard he needs to possess particular attributes. If he is wrong he bears a loss. If he is right in this risk-taking function, profit accrues to the entrepreneur with sound foresight, self-confidence and judgment, usually when he acquires inputs for less than their combined worth. These characteristics are not tradeable, but complementary to other productive assets, thus making it logical for the entrepreneur to own assets and form a business (Foss and Klein, 2012). 


\section{Some Entrepreneurship Ideas from the Austrian and Modern Economic Schools}

Schumpeter (1934) regards innovation as the essence of entrepreneurship. The entrepreneur is an innovator. The Schumpeterian entrepreneur brings about changes in the production function in terms of new combinations, upsetting a steady equilibrium state in which all behaviour from agents is based on mere routines. The consequences of these new combinations are innovation, and individuals whose function is to carry them out are 'entrepreneurs' (Schumpeter, 1934: 74). He brings about innovation by introducing a new product or improving the quality of existing goods, opening of a new method of production, opening of new markets, the conquest of new sources of supply of raw materials and creating of a new type of organization or reorganizing of an industry.

Schumpeter viewed the regular management tasks as less entrepreneurial once the start-up phase of a venture has passed. Thus, one is only an entrepreneur when one carries out new combinations and subsequently loses that character as soon as he has built up the business and he settles down to running it as a routine management function of a going entity.

The Schumpeterian entrepreneurs are heroic figures in advancing economic development. They are the creative individuals who perceive profitable opportunities for new combinations and hire the necessary inputs for their exploitation. But they are a relatively scarce class of 'special people' (Lucas, 1978), and their innovative actions of 'creative destruction' requires an act of will, i.e. leadership and not intelligence only. What motivates individuals to embark on an entrepreneurial career? Schumpeter (1934: 93-94) suggests three motives. These are:

- the dream to found a private kingdom and possibly a dynasty,

- the will to fight and conquer and prove oneself superior to others, and to succeed, not for the sake of fruits of success, but of success itself,

- the joy of creating or getting things done.

For Israel Kirzner, who also belongs to the Australian school of economics, the entrepreneur is an 'arbitrageur' who discovers a discrepancy in present prices that can be exploited for profitable exchange opportunities. His function is 'to notice what other people have overlooked' (1982: 273) so that he may spring into action within a given set of markets. In the Kirznerian framework, there is no necessity for the pure entrepreneur to own resources.

The distinguishing attribute of the Kirznerian entrepreneur is alertness and vision to identify market gaps and exploit profitable opportunities. The entrepreneur has some additional knowledge or superior cognitive capabilities that others may not possess, enabling him to discover, evaluate and exploit profitable opportunities that others might not have yet noticed. However, Kirzner (1976: 121) adds that "we do not clearly understand how entrepreneurs get their flashes of superior foresight". Once an opportunity has been identified, his task becomes that of a manager. "If people know that a gap is to be filled, and that it is worthwhile to fill, the task is no longer entrepreneurial; it can be handled by competent managers through routine production methods" (Kirzner, 1982: 276).

Drawing from the ideas of Knight, Casson (2003: 23) views an entrepreneur as someone who specializes in taking judgmental decisions about coordination and employment of scarce resources. He emphasizes that the entrepreneur will have different skills from others. The entrepreneur needs to have access to resources to ensure effective exercise of his judgmental decision making function. Individuals with entrepreneurial ability but without access to resources are excluded from entrepreneurship. 
In perfect competitive markets, the supply of and demand for entrepreneurship are assumed to adjust automatically. But in reality as imperfect competition is the norm, we do not have perfect competitive markets. Although there is an increase in the demand for entrepreneurs in South Africa, as in many other countries, this does not necessarily translate into an increase in supply, partly because of entrepreneurial capacity constraints and environmental limitations, such as crimes, security, red tape or regulations and inadequate skills, education, training and work experience. According to GEM reports, South Africa's early-stage entrepreneurial rate was between 7.8 and 9.1 during the period 2008-2011 (Herrington, 2012). Any environmental circumstances which reduce profit would restrict entrepreneurial roles to exploit opportunities and inhibit the supply of entrepreneurs.

Extending a human capital approach to entrepreneurship, Schultz (1980) argues that entrepreneurial ability can be increased through investment in education, training, experience and health care. Just like the case of individuals in other occupations, Schultz argues that entrepreneurs too can learn by doing and by training. As such the entrepreneurial function can be potentially performed, not by just an exclusive class of specialists, but by most individuals, if they have the right skills. Thus, the supply of entrepreneurship can be elastic, and this can make an impact on reducing South Africa's frightening unemployment problem, which has reached an alarming rate of between $25 \%$ and $35 \%$ (expanded definition) in 2013 (SARB, 2013).

Accepting this, there is every merit for South Africa to invest in human capital. It is noteworthy, that concerned about human and entrepreneurial development, South Africa is spending over $20 \%$ of its national budget on education. South African education was historically drafted such that a person would be employed rather than self-employed (Van Aardt, Van Aardt, Bezuidenhout and Mumba, 2008). Accordingly, the government of today has intervened with numerous skills programmes through various SETAs to boost people's business skills, and specific institutions, such as Khula and Seda, to assist actual and potential business persons with capital and advice. This is beneficial not only in terms of enhancing South Africa's stock of entrepreneurial ability but also in attaining the Millennium Development Goals of reducing poverty, creating job opportunities and enhancing capacity building, growth and development by 2015 and beyond, in the spirit of the country's new National Development Plan.

Scott Shane reasons that entrepreneurship links opportunities to individuals with certain psychological and creative attributes. He defines entrepreneurship as an activity that involves discovery, evaluation and exploitation of opportunities to introduce new goods and services, and organize new markets, processes and raw materials through coordinating efforts of the entrepreneur that previously did not exist (Shane, 2003: 4). He adds that entrepreneurship "involves the nexus of entrepreneurial opportunities and enterprising individuals ... where a situation in which a person can create a new means-ends framework for recombining resources that the entrepreneur will yield a profit" (Shane, 2003: 18). Once opportunities have been discovered and evaluated, their exploitation lead to the acquisition of resources, strategy implementation, organizing and performance.

Taking a resource-based approach to firm capabilities and growth, Edith Penrose (1995) regards the firm as a collection of productive resources, driven largely by the versatility of the entrepreneur. The management of the firm is a source of both entrepreneurial and managerial services, and these may be provided by the same person in the small venture. However, while managerial versatility is simply a matter of 'administrative or technical competence', entrepreneurial versatility is a question of 'imagination and vision' (Penrose, 1995: 36). The neoclassical school assumes that knowledge, in keeping with the principles of perfect competition, is free and instantly disseminated. But Penrose takes an alternative view, arguing that knowledge is not always easy to acquire, while labour, capital and 
resources are generally available. Similarly, Stiglitz (2002) contends that the market for information and knowledge is highly imperfect. Knowledge as a resource base then becomes a key differentiating factor in the success of a competitive enterprise.

Although classical and modern economists have made pioneering contributions to entrepreneurship and the role of the entrepreneur in advancing the economic and business development process, in recent decades the study of entrepreneurship has spanned across other disciplines. Interesting insights into entrepreneurship are also offered in management literature. This is briefly examined in the next section.

\section{DRUCKER AND ENTREPRENEURSHIP IN MANAGEMENT LITERATURE}

The management school associates classical entrepreneurship with new venture creation and entrepreneurs as those individuals who launch a business. Accordingly, entrepreneurship is often used in the context of small business (Venter, Urban, Rwigema, 2011: 5). Further, Nieman and Nieuwenhuizen (2009: 9) add that entrepreneurship is the emergence and growth of new businesses. There can be different categories of firms, ranging from subsistence, micro ventures to high-profile ventures.

Shane and Venkataraman (2000: 218) define the field of entrepreneurship as a "scholarly examination of how, by whom and with what effects opportunities to create future goods and services are discovered, evaluated and exploited". Certainly, there is much more to this, as once a business starts up, it needs to be managed well, to ensure its survival and growth. Entrepreneurship is practiced in existing and new ventures. It is not the same thing as management. The skills required to launch a business are different from those required to manage a business.

The entrepreneur can perform the role of both the promoter and the manager. In the small business, most managerial functions are performed by the owner-manager, founding entrepreneur. If he hires someone to look after operational aspects of the business, then that person is an administrator or trustee-manager. He is likely to operate under a contractual agreement. The entrepreneur-promoter is the individual manager, who views the pursuit of an opportunity as being both desirable and feasible. He feels confident in his ability to seize opportunities, regardless of the resources under his control. He seeks independence, initiates and manages ventures and feels satisfied to be his own boss. On the other hand, the administrator-manager is preoccupied with the effective utilization of existing resources. He takes given materials, people, capital, machines and other resources and orchestrates them into measurable output or production. While the promoter actively seeks change, the trustee-manager responds more passively in terms of rewards offered. He brings ventures to fruition.

According to Drucker (1997), entrepreneurship rests on management principles. Entrepreneurship is defined as doing something innovative in order to obtain better yields on resources and expand markets for a product or service.

"Entrepreneurs innovate. Innovation is the specific instrument of entrepreneurship. It is the act that endows resources with a new capacity to create wealth. Innovation, indeed, creates a resource. There is no such thing as a resource until man finds a use for something in nature and then endows it with economic value. Until then, every plant is a weed and every mineral just a rock" (Drucker, 1997: 27).

The entrepreneur, in Drucker's (1997) view, should be opportunity-focused to accommodate, anticipate and initiate change, and introduce innovation in business organizations and 
public-sector institutions. He regards "innovation as the specific tool of entrepreneurs" (1997: 17). This role of the entrepreneur is similar to those of Schumpeter, who also emphasized that the entrepreneur is an innovator, seeking opportunities to carry out new combinations. According to Drucker, the opportunities for innovation may arise from various sources, internal and external to the firm. These include:

- the unexpected (a success, failure or exogenous event)

- incongruities

- new approaches to process needs

- changes in industry or market structure

- changes in demographics

- changes in perception, mood and meaning

$\circ$ new knowledge and bright ideas.

This role of the entrepreneur is similar to those of Schumpeter, who also emphasized the entrepreneur as an innovator, seeking opportunities to introduce new combinations in various forms. An entrepreneurial society is driven by the activities of these innovative entrepreneurs. Although ideally entrepreneurial activity is embodied in the creation of new firms, it is necessary for entrepreneurship to flourish within large business organisations, and for this, they need an entrepreneurial management structure with a corporate strategy, reflecting what the firms should be doing. Professional managers can only secure their own security if their firms are secure, profitable and innovative. These accrue from responding to opportunities in the environment. "Companies that have built entrepreneurial management into their structure ....continue to be innovators and entrepreneurial leaders, irrespective of changes in chief executives or economic conditions" (Drucker, 1997: 156).

\section{Synthesis}

Entrepreneurship as alertness to spot and exploit opportunities was initially championed by both the classical and Austrian schools. Over the past decade alertness to profit opportunities has featured prominently in the management literature in entrepreneurship

(Shane and Venkataraman, 2000). Shane (2003) regards entrepreneurial opportunities in the context of new means-ends frameworks, which is in the Kerznerian or Schumpeterian spirit. Although Shane's "new" means-ends framework is seemingly different from the classical optimizing framework, he seems to be aligning with the Schumpeterian thinking on innovation. There seems to be some convergence in thinking between the two schools. While for the modern management scientist, opportunity recognition, evaluation and exploitation are critical aspects of entrepreneurship, for Kirzner, recognition is the primary entrepreneurial act, the rest is management (Foss and Klein, 2012).

In systematically exploring and exploiting the above opportunities, the entrepreneur is essentially a risk-taker and a risk manager. He manages risk through preventive measures, such as taking insurance, and through pro-active strategies that enable him to influence or adapt to changing business conditions. So in the Druckerian perspective, everyone who can face up to decision-making under conditions of uncertainty can be an entrepreneur and can learn to behave entrepreneurially. This implies that one is not necessarily born as an entrepreneur, but one can be trained and study to become one. In short, for Drucker, the practice of entrepreneurship and innovation is not inborn characteristics, but a learnable and doable behaviour. "Entrepreneurship, then, is behaviour rather than personality trait" (Drucker, 1997: 23).

The ability of the entrepreneur to learn is critical to his behaviour to respond creatively to a constantly changing environment. This suggests that human capital in the form of knowledge, skills and experience acquired by individuals is important in fostering entrepreneurship (Becker, 1975). 
Essentially, therefore, in the Druckerian view, entrepreneurship is an approach to management to introduce innovation that can be learnt and practiced. Earlier, Theodore Schultz (1979) also viewed entrepreneurship as an aspect of human behaviour that is capable of being exercised by most people with the ability to adjust or reallocate resources in response to changing circumstances, which can be sources of opportunities. As such, entrepreneurship is not simply restricted to businesspersons, but farmers, housewives, students, deans and university top decision makers and research directors form part of Schultz's set of entrepreneurs. Further, Schultz (1980) argued that entrepreneurship among individuals can also be enhanced through education, training experience and health care.

Jovanovic (1982) finds that differences in entrepreneurial ability, learned over time, determine a person's entry or exit. As individuals acquire more business experience, they may formulate better estimates of their ability to expand the firm, and contract the firm if they discover a lower entrepreneurial ability. Instead of contracting, some may exit from entrepreneurship. Holmes and Schmitz (1980) predict that the least able types of entrepreneurs will take over and manage existing firms, while those with more capabilities will specialize in setting up new businesses, perhaps as serial entrepreneurs. Accordingly, in many schools of business and management studies, entrepreneurship and enterprise education is offered as part of the curricula. The phenomenon under study is usually small business entrepreneur, business incubation and the effective exercise of entrepreneurial management functions, in the form of organizing, directing, control and leadership, as well as raising finance and drawing up a business plan.

\section{N-ACH AND THE PSYCHOLOGICAL SCHOOL}

Entrepreneurship is difficult to work into formal economic analysis because of its association with the temperament and personal qualities of individuals (Penrose 1995). Can one identify a trait that allows for the identification of an entrepreneurial personality? This takes us to the psychological school. According to McClelland (1961) a key feature in the psychological motivation of individuals conducive to entrepreneurial activity is the need for achievement, also known as n-Ach. The critical element linking n-Ach to economic and business development is the entrepreneur. He organizes the firm, increases its productive capacity and translates n-Ach into economic development.

$\mathrm{N}$-Ach is described as the urge to improve, the motive to succeed competitively with some standards of excellence, and the desire to do well, not so much for the sake of social recognition or prestige but to attain an inner feeling of accomplishment. McClelland (1961, 1986) associates with high need achievement:

- personal effort and self-confidence,

- opportunity seeking and pro-activeness to make things happen,

- responsibility for solving problems

- setting goals that are both challenging and realistic,

- moderate risk preferences,

- seeking concrete feedback on performance,

- capacity to plan ahead, and

- effective use of time as a scarce resource.

The achievement drive of individuals varies from one person or country to another, and across cultures. At the macro level, McClelland contends high n-Ach levels are associated with above-average economic growth: a society with a generally high level of need achievement tends to produce more energetic entrepreneurs who in turn produce more rapid economic development (McClelland, 1961: 205). At the micro level, a positive relationship is 
found between people's n-Ach and their entrepreneurial success in South Africa and other countries. Individuals high in n-Ach attain greater success in business than those low in $\mathrm{n}$ Ach (Van der Merwe,1984; Boschoff and Boer, 1988; Van Daalen, 1992, Mahadea, 1994, 2001; Bridge et al, 2009).

Psychological evidence indicates that $n$-Ach is instilled early in life and child rearing practices are critical in developing personalities oriented towards achieving economic success. The influence of parents is thus critical for $n$-Ach, particularly mothers who set reasonably high standards for their children at a time when they can reasonably attain them without excessive interference, overprotection and indulgence (McClelland, 1986).

Some individuals might have had difficult childhood experiences, possibly impacting adversely on their potential $n$-Ach and entrepreneurial propensities. However, according to McClelland, n-Ach levels can still be developed or strengthened in adults through appropriate training and potential entrepreneurs can thus be trained to succeed. This implies that latent development motivations of individuals can be stimulated through relevant policy interventions and, over time, these, combined with practical training in management, marketing, finance and project development, the supply of effective entrepreneurs or entrepreneurship can be increased.

A high $\mathrm{n}$-Ach is an important trait not only for successful entrepreneurs and also for the success of people in many other occupations, including managerial and leadership positions. Literature has identified other traits as critical to entrepreneurship. Witt (1998), for instance, describes cognitive leadership to be associated with entrepreneurship. Entrepreneurs need to have the ability to communicate plans, visions and strategies to others and harness the skills of people and other resources to start and develop a firm. Researchers have identified other personality attributes, common among high $\mathrm{n}$ Ach people that are conducive to entrepreneurship. These include self-confidence, optimism, locus of control, extraversion, tolerance of ambiguity, imagination, leadership and creativity (Rotter, 1966; Timmons, 2007, Shane and Barron, 2008; Bridge at al, 2009; Foss and Klein, 2012).

\section{Acquired or innate attributes}

Some of the above traits are certainly genetic in that some individuals are born with them, making natural entrepreneurs as a scarce breed. Indeed, Harrison (2005: 49) argues that individuals have certain talents encoded in their DNA genes and entrepreneurs have an inborn predisposition to thinking and acting in a certain ways that contribute to their success. To avoid inertia, these talents have to be 'switched on' for successful entrepreneurship. However, the presence of one trait does not always guarantee success, but lacking an achievement motivation drive contributes to failure in any entrepreneurial endeavor in the long run.

Many of the characteristics of successful entrepreneurs are also common to managers. Luckily some of these attributes, according to Deakins and Freel (2012) and others (Timmons, 2007; Bridge et al, 2009) can be acquired through training, experience and human capital development. After all, personality characteristics are not always stable. These may change over time as individuals are exposed to different learning and resource environments. One can thus criticise research that seeks to develop successful entrepreneurs purely on the basis of personality profiles. Concentrating on personality traits implies that we are overlooking the environmental and cultural influences, as well as reducing the importance of education and training on the propensity of an individual to venture into small business entrepreneurship. 
Accordingly, one can argue that some entrepreneurs can be 'made' or 'developed' to increase the supply of entrepreneurship. However, it is an indisputable fact of life that high profile entrepreneurs are, to some extent, a product of genetics and family or environmental circumstances, and that some of the skills natural to entrepreneurship cannot be taught. Indeed, Timmons (2007) and Casson (2003) describe some attributes which are more innate and cannot be so easily acquired. These include:

- Vision combined with a capacity to inspire

- Creativity and innovativeness

- Conceptual ability

- High energy, health and emotional stability

- Imagination

Although some entrepreneurial traits are innate and some can be enhanced through education and training, it is reasonable to argue that some of these attributes are scarce and difficult to screen for among individuals prior to their entry into self-employment. Accordingly, in the short term, the supply of high profile entrepreneurship can be relatively inelastic. Encouragingly, with proper empowerment interventions, such as provision of relevant training, finance and market opportunities, there is always a possibility that latent or dormant entrepreneurial skills in some individuals can develop and flourish in the long run.

From the foregoing, it is clear that a high level of $n$-Ach is clearly necessary but not the only key factor in motivating entrepreneurship. People of different personality types, attitudes, cultural backgrounds, motivations and skills can become entrepreneurs and succeed in their roles, if given the opportunities or incentives to evolve. Timmons (2007) and Penrose (1995) suggest that research should rather study the behaviours, skills and activities of entrepreneurs to isolate the role that they play in enabling viable organizations to come into existence and remain competitive. From this perspective, entrepreneurship is a role that an individual undertakes to create organizations and keep them competitive. So, what distinguishes the entrepreneur from the non-entrepreneur is that the entrepreneur creates firms whereas the non-entrepreneur does not (Gartner, 1988; Gartner and Bellamy, 2009).

\section{TOWARDS AN ECLECTIC VIEW}

As there is some overlap between different schools of thought on entrepreneurship, there is as yet neither an uncontested understanding of the nature of entrepreneurship nor a universally accepted function of the entrepreneur. Different authors define entrepreneurship differently. Those who emphasise his organizing role as a higher form of labour, perceive him as a manager or a co-ordinator. To those who stress his creative ability under conditions under uncertainty, he is an innovator and a risk-taker. Those who add the effects of superior knowledge that animate entrepreneurial competition, stress the entrepreneur's role in terms of alertness, perception of and adjustment to disequilibrium (Lucas, 2009). The essence of entrepreneurship thus lies not in one specific function but in a range of disparate activities performed by different personality types and capabilities.

No matter what role is adopted for entrepreneurship, it is certainly not a routine activity. It is concerned with discovery, evaluation and implementation of actions or ideas to exploit profitable opportunities, in particular circumstances of a new or preferred ends-means framework. This characterization of entrepreneurship comes close to that of Shane. These actions need access to resources and co-ordination, and are driven by the entrepreneur and his team. There are as many kinds of change as there are many concepts of the entrepreneurial function associated with different types of firms and individuals as entrepreneurs. This distinguishes entrepreneurship from routine management, which is concerned with the recycling activities of an organization. 
It is an undoubted fact that no one is an entrepreneur all the time, and that nobody can be only an entrepreneur. Equally, once a firm has been established to exploit a perceived opportunity, running it as a going concern will increasingly become a managerial task. Individuals high in n-Ach and human capital tend to exhibit more organizational skills in the conduct of their ventures, and tend to launch more sophisticated ventures and perform better relative to those low in $n$-Ach (Mahadea, 1994, 2001). Thus, there is a need for both entrepreneurial and managerial services from the moment of the conception of a business idea to the establishment of a firm which can be described as a going concern. During this period, the mix of entrepreneurial and management services might be thought of as a continuum.

The management literature does not seem to have fallen into the economists' approach of viewing entrepreneurs as performers of functions valuable to the economy rather than as hired people asset to manage the existing resources of the firm and an extension of the existing enterprise. They perform functions like planning, organizing, human resource management, marketing, leading, hiring and controlling. Entrepreneurs who are high in need achievement tend to be pro-active and to act fast realising that time is a non-renewable resource and a window of opportunity is unlikely to remain open indefinitely. They take risks and accept responsibility for decisions and provide solutions to business problems. On the other hand, this literature has given little explicit attention to the entrepreneur's external economic role, such as contribution to GDP and employment. The role referred to here is partly the function of managing an existing venture or the creative function attributable to existing firms under disequilibrium conditions, as partly described by economists. As Wickham (2005: 111) succinctly puts it, entrepreneurship is concerned with the economic effects of, and the management practice of entrepreneurs. As a part of strategic management, it is a skill that can be practiced and perfected in a human business setting. What emerges from the management literature's conception of the entrepreneur, therefore, is a portrait which complements the economists' conception.

Both schools associate entrepreneurship with the creation of enterprises and change. In this respect, the entrepreneur's role can hardly be discounted, since a business firm cannot start itself and opportunities cannot be exploited without the agency of the entrepreneur. While new ventures are created by entrepreneurs, all small businesses are not necessarily entrepreneurial firms. Many are started as 'lifestyle' ventures, with limited growth ambitions or objectives (Venter et al, 2011). However, if analysts are to classify all owner-managers of small non-innovating firms, who are almost exclusively engaged in normal management functions, as entrepreneurs, then they should explicitly be recognized as a qualitatively lower form of entrepreneurs than those in the dynamic firms, who carry out new combinations in the Schumpeterian sense. Likewise, those who engage in a low value-adding business in the informal sector or street-vending, and who started it by necessity because of lack of alternative employment opportunities, should be regarded as a lower or nascent form of entrepreneurship. Over time, with benefits of learning by doing and networks, some of these emerging entrepreneurs may graduate to the formal sector.

\section{Elements of entrepreneurship in the context of large firms}

In the context of a large business, some aspects of entrepreneurship are delegated and thus performed by certain managers or employees in the hierarchy, with requisite skills and knowledge. This may be a form of intrapreneurship or corporate venturing. The managers act entrepreneurially, take strategic decisions jointly to bring about innovation within the mainstream activities, from which new products may spun out. However, with regard to the small and micro-enterprises, delegation may be difficult and this makes the owner-manager as the sole entrepreneur with the decision-making authority and main point of accountability. 
He then takes the ultimate decisions regarding what to produce, for whom to produce, what resources to hire and how these resources are to be deployed or transformed into new forms and perspectives (the means).

At times, loans have to be raised from financial institutions through the presentation of a business plan. However, although the small firm entrepreneur makes the 'ultimate' decisions regarding resource allocation, this does not imply that he prepares the entire content of the firm's business plan when it has to raise external finance to supplement his own resources. In this regard, plans may be drawn up by outside managers and consultants. But the implementation of the plan to reflect the mission, direction, strategy and conduct of the firm remains his decision and responsibility.

Indeed, it is perhaps to the modern major corporations that one should turn to obtain additional insights into the nature and scope of entrepreneurship. In an age of global connectivity, business organizations should undertake a continuing assessment of their strategy and tactics to match the changing environment and reposition themselves to an intended outcome of growth and organizational renewal and steer away from a wrong direction (Sunter, 2013; Illbury and Sunter, 2005). The decisions which flow from this exercise will determine how organizational resources will be used, rearranged or adapted to enter new markets with improved existing products, old markets with new products or new markets with new products. As firms and entrepreneurs are engaged in activities with diverse levels of technical and operational sophistication, and do not possess the same strengths, capabilities and strategies, the resources they use or have access to tend be heterogeneous rather than homogenous.

Decisions to leave certain product-markets in certain regions or relocate to certain other regions are also taken. New divisions or branches may be structured or downsized within existing corporate identities or new companies may be formed. Taxation, rebates, labour unrest, assistance to firms in financial distress, and new labour and broad based Black Economic Empowerment (BEE) legislations often dictate how a new venture might be launched or an existing firm be restructured legally. The organizational forms taken and types of activities engaged in, whether manufacturing or agriculture or retailing, are unimportant in the context of entrepreneurship. What is important is that decisions are taken, under conditions of uncertainty, which commit the organisation's major resources to particular directions for value adding for some years ahead, in recognition of opportunities and threats (Mahadea, 2000). The entrepreneurs are often motivated by extrinsic (profit) and intrinsic goals (desire for independence), as well as by unmet social considerations, to address poverty or HIV/Aids (social entrepreneurship).

\section{Elements of entrepreneurship decisions in a small firm}

In making a decision to take the entrepreneurial route to self-employment in a small business, an individual will compare the uncertain expected utility from self-employment with certain utility from wage-employment. If utility is greater in self-employment, proxied in terms of expected earnings or non-monetary rewards with freedom of being one's boss, than in wage employment, then he shifts to entrepreneurship. In other words, if the opportunity cost is low and net rewards are high, the subjective decision to take the entrepreneurship route is a preferred option. Entrepreneurial decisions are thus continuing decisions that are taken by those who control economic resources or have access to them.

Decisions are made on the basis of cold facts, with a proper assessment of opportunities and gaps in the market and an alignment of the strength of the entrepreneurs or their firms to exploit and create opportunities. As available information or knowledge is not necessarily perfect under changing environmental conditions because of bounded rationality and 'brain 
power' limitations, decisions made under uncertainty by the entrepreneurial persons are likely to be based on cognitive heuristics rather on optimizing calculus/choices (Kahneman, 2011). Entrepreneurs with larger stock of human capital, in terms of education, vocational training, and information knowledge and ideas, are better placed to exploit opportunities via new ventures and adapt their enterprises to the constantly changing business environment (Parker, 2009; Nieman and Nieuwenhuizen, 2009; Herrington, 2012).

As access to resources can be a limitation in certain circumstances, then the entrepreneurial decision leading to the emergence of the firm is through an effectuation process (Sarasvathy, 2001). Effectuation is described as the logic of entrepreneurial approach, a dynamic and interacting process of creating the new artifact (Sarasvathy, 2008). This implies that the constraint entrepreneurs start with an aspirational level with the means available (who I am) and develop creative ideas and courses of action (what can I do) by tapping existing resources at their immediate disposal, possibly interacting with other stakeholders (who I know), to make things happen (outcome) in the context of starting a new business, that is 'selecting between means to create that effect' (Sarasvathy, 2001: 245; Sarasvathy, 2008).

The owners of progressive small businesses are generally actively involved in such decisionmaking and they thus usually do control the resources at the disposal of the firm. Successful small firms are the seed of medium-sized and large firms. In the larger firms, the institutional shareholders and the Board of Directors might exercise effective control. The modern entrepreneur is thus someone who effectively controls resources and take strategic decisions to exploit business opportunities. As Reekie (1989: 189) argues, decisions "as to what lines of business to employ capital (in) and how much capital to employ ...(decisions as to) expansion and contraction of the size of the total business, and its main sections ... (decisions as to its) financial structure' fall upon the entrepreneur alone. Entrepreneurship is then the ongoing activity of making and implementing decisions which will govern the marshalling and utilization of resources with a view to the formation and expansion of firms, thus adding value to the satisfaction of consumer and societal needs. The outcomes are wealth creation, production and distribution of goods and services that did not exist before. These economic activities contribute to enhancing the levels of output (GDP), income and employment. The entrepreneur has to exercise judgment under conditions of uncertainty. Judgment is the faculty of decision-making about resource uses; it is the act of owning and controlling productive resources (Foss and Klein, 2012: 237). This is essentially a behavioural approach. When opportunities are combined with entrepreneurs' and other individuals' skills and motivation, the outcome is creation of new firms, and consequently economic growth and employment creation (De Clercq and Crijns, 2007).

Some top managers of large organizations spend most of their time taking entrepreneurial decisions on an ongoing basis. This has gained more currency with globalization as organisations are under constant pressure to adapt their internal resources, strategies and policies to match the changing external business environment. Companies are thus continually having to make almost daily decisions to effect changes in relation to meeting the needs of their customers, suppliers, workforce and other stakeholders. This is to ensure that they have the capacity to exploit present and future opportunities and withstand environmental threat for enhanced competitive advantage and sustainability. The large firms that make good decisions and act on them fast have higher metabolism, enabling them to exploit opportunities and overcome obstacles quickly.

In contrast, the initiator of a small business, formal or informal, on the other hand, often commits his major resources in such a way that that no major review or repositioning is possible for years to come. He is more concerned with operational decision-making process. There is one burst of entrepreneurial decision-making followed by years of operating a 'going 
concern' with basic management tasks. However, the role and behavior the entrepreneur may change as the internal situation of the firm becomes more established over time with the prevailing economic, political, social, and technological circumstances, which allow an appreciable measure of freedom of decision. Decision-making then becomes more formal, involving a clear process of rules, procedures, tasks delegation, accountability and responsibility. Entrepreneurship must accordingly be conceptualized not in terms of function or personality but in terms of decision-making with substantial ownership and commitment of resources on the part of the entrepreneur. This is essentially an eclectic perspective that will probably satisfy the needs of economists as well as management scientists.

Whatever the strength of these interpretations, it should be stressed that the concepts of entrepreneurship and management alter over time with economic progress and the changing environment in which businesses operate. Entrepreneurship as a discipline and as a business decision activity will evolve over time. Entrepreneurship is increasingly taking on a multidisciplinary orientation.

\section{CONCLUSION}

Entrepreneurship is a complex process, within new and existing firms. As an economic phenomenon, entrepreneurship has been conceptualized under diverse circumstances in different historical epochs. The exercise of entrepreneurship is not confined to small firms exclusively. To the extent that individuals can take ultimate decisions and take responsibility for their actions in their particular circumstances, they are all entrepreneurs to a small or great extent.

No matter what specific definition or function one may adopt for entrepreneurship, it is inherently non-routine. Entrepreneurship runs parallel with the entrepreneur. The main agent in entrepreneurship is the entrepreneur.

Modern schools of economic thinking view the entrepreneur as a decision maker responsible for venture creation and economic expansion in response to opportunities. The economic approach positions the entrepreneur as a creative person, driven by the need to produce a good or a service and add value to society. However, entrepreneurship may be allocated to unproductive or destructive activities, when 'rules of the game' tend to favour certain activities, such as crime, rape, corruption and gangsterism, if the reward structures from these activities are very high and the culprits unlikely to be caught (Baumol, 1990). A favourable social climate is thus a necessary pre-condition for the development of productive entrepreneurship in any society. Therefore, to establish the foundations for a successful entrepreneurial economy in South Africa, that has a low early stage Total Entrepreneurial Activity (TEA) rate of (9.1\%) relative to other efficiency-driven economies (14\%) in 2012 (Herrington, 2012), government must discourage activities that divide the economic pie rather than increase its size. Further, government institutions must ensure that winning entrepreneurs and larger businesses have incentives to innovate and grow, and there must be institutions that reward and support useful entrepreneurial activity, through property, credit and contract rights (Baumol, 2010), as well as address the education, training and environmental needs in support of individual decision-making propensity towards business entrepreneurship (Mahadea and Simson, 2011; Herrington, 2012).

Other schools highlight a complementary functional role of the entrepreneur. Although the tasks of entrepreneurs cannot be completely defined, certain traits partially indicate their profile. To McClelland, enhancing n-Ach is critical for entrepreneurship. To Drucker, the entrepreneur should be opportunity-focused to bring about innovation, and all organizations 
should behave entrepreneurially and practice entrepreneurship for maximum individual and national prosperity. This cannot happen in a vacuum.

The eclectic view associates entrepreneurship with continuing smart decisions under uncertain conditions regarding resource allocation to add value to society by those in control of economic resources of the firm. Entrepreneurship is essentially an interdisciplinary subject. There is much to admire in contemporary entrepreneurship theory in management as well as in economics (Foss and Klein, 2012: 248). Clearly, no single disciplinary framework can explain the wholeness of the entrepreneurial phenomena. Consequently, "entrepreneurship must be studied in context, from a multidisciplinary perspective and using multiple levels of analysis" (Griffiths, Kickul, Bacq and Terjesen, 2012: 623)

\section{REFERENCES}

Baron, R. A. and Shane, S. A. (2008): Entrepreneurship: A Process Perspective, SouthWestern Cengage Learning, $\mathrm{OH}$, USA.

Baumol, W. J. (1990): Entrepreneurship: Productive, unproductive and destructive. Journal of Business Venturing, 11 (1): 3-22.

Baumol, W. J. (2010): The Microtheory of Innovative Entrepreneurship. Princeton University Press, Princeton, $\mathrm{N}$ J.

Becker, G. (1975): Human Capital, New York: National Bureau of Economic Research.

Boschoff, A. B. and Boer, J. H. (1988): N-Ach training, organizational climate and organizational performance. Development Southern Africa, 5(1): 73-87.

Bridge, S., O'Neill, K. and Martin, F. (2009): Understanding Enterprise, Entrepreneurship and Small Business. Palgrave Macmillan, London.

Casson, M. (2003): The Entrepreneur: An Economic Theory. Martin Robertson, Oxford.

Deakins, D and Freel, M. (2012): Entrepreneurship and Small Firms. McGraw Hill, London.

De Clercq, D. and Crijns, H. (2007): Entrepreneurship and Education in Belgium: Findings and Implications from the GEM, in Handbook of Research in Etrepreneurship Education, ed A. Fayolle, Edward Elgar, London, 169-184.

Drucker, P. (1997): Innovation and Entrepreneurship, Oxford: Butterworth-Heinemann.

Foss, N. J. and Klein, P. G. (2012): Organizing Entrepreneurial Judgment, Cambridge University Press, Cambridge.

Gartner, W. G. and Bellamy, M. G. (2009): Creating the Enterprise, Thomson SouthWestern, Canada.

Gartner, W. G. (1988): Who is an Entrepreneur? Is the Wrong Question, American Journal of Small Business, 12 (4): 11-32.

Griffiths, M. Kickul, J., Bacq, S. and Terjesen, S. (2012): A dialogue with William J. Baumol: Insight on Entrepreneurship Theory and Education, Entrepreneurship Theory and Practice, 36 (4): 611-626. 
Harrison, T.L. (2005): Instinct: Tapping Your Entrepreneurial DNA. Warner Books, New York.

Herrington, M (2011): Entrepreneurship: How Can Obstacles be Overcome?, in Advocates for Change, ed M. Mbeki, Picador Africa, Johannesburg, 115-136.

Herrington, M (2012): African Entrepreneurship Lacking!, Business Brief, 17 (5): 14.

Holmes, T. J. and Schmitz, J. A. (1990): A theory of Entrepreneurship and its Appication to the study of Business Transfers, Journal of Political Economy 98 (2): 265-94.

Illbury, C. and Sunter, C. (2005): Games Foxes Play, Human and Rousseau Tafelberg, Cape Town.

Kahneman, D. (2011): Thinking, Fast and Slow, Penguin, London.

Kirzner, I. M. (1973): Competition and Entrepreneurship, University of Chicago Press, Chicago.

Kirzner, I. M. (1976): Equilibrium versus Market Process, in E. G. Dolan, ed. The Foundations of Modern Austrian Economics. Sheed and Ward, Kansas City, 115-125.

Kirzner, I. M. (1982): Competition, Regulation and the Market Process: An Austrian Perspective. Cato Policy Analysis, No 18, September 30.

Kirzner, I. M. (2009): The Alert and Creative Entrepreneur: A Clarification, Small Business Economics, 32 (2): 145-152.

Kirzner, I. M. (1982): 'The Theory of Entrepreneurship in Economic Growth' in Kent, Sexton Vespers (eds.), Encyclopedia of Entrepreneurship, Prentice-Hall, New York.

Knight, F. H. (1921): Risk, Uncertainty and Profit. A. M. Kelley, New York.

Lucas, R. E. (1978): On the Size Distribution of Business Firms, Bell Journal of Economics, 9 (4): 508-523.

Lucas, R. E. (2009): Ideas ad Growth, Economica, 76 (1): 1-19.

Marshall, A. (1890): Principles of Economics, Macmillan, New York.

McClelland, D. C. (1961): The Achieving Society, Van Nostrand, Princeton, N.J.

McClelland, D. C. (1986): Characteristics of Successful Entrepreneurs. Journal of Creative Behaviour, 21 (3): 219-232.

Mahadea, D. (1994): Need Achievement and Small Business Success in Transkei. Development Southern Africa, 11 (1): 93-98.

Mahadea, D. (2000): On the Emergence of Firms and Sick Institutions, South African Journal of Economics and Management Sciences, 4 (1): 31- 40. 
Mahadea, D. (2001): Similarities and Differences between Male and Female Entrepreneurial Attributes in Manufacturing Firms in the Informal Sector in the Transkei. Development Southern Africa, 18(2): 190-199.

Mahadea, D. and Simson, R. (2011): Work without Workers: What Happened to Employment in South Africa?, in Jobs, Jobs, Jobs (ed. Nolutshungu, A.), Free Market Foundation, Johannesburg. 182-212.

Nieman, G. and Nieuwenhuizen, C. (eds), (2009): Entrepreneurship: A South African Perspective. Van Schaik, Pretoria.

Parker, S. C. (2009): The Economics of Entrepreneurship, Cambridge University Press, Cambridge.

Penrose, E. (1995): The Theory of the Growth of the Firm, Oxford, London.

Ramphele, M. (2012): Conversations with My Sons and Daughters, Penguin, London.

Reekie, W. D. (1989): Industrial Economics: A Critical Introduction to Corporate Enterprise in Europe and America, Edward Elgar, Aldershot.

Rotter, J. B.(1966): Generalised Expectancies for Internal versus External Control Reinforcement, Psychological Monographs, 80 (9): 609-610.

Sarasvathy, S. D. (2001): Causation and Effectuation: Toward a Theoretical Shift From Economic Inevitability to Entrepreneurial Contingency, Academy of Management Review, 26: 243-263.

Sarasvathy, S. D. (2008): Effectuation: Elements of Entrepreneurial Expertise, Edward Elgar, Cheltenham, U.K.

Schultz, T. W. (1980): Investment in Entrepreneurial Ability, Scandinavian Journal of Economics, 82(4): 436-463.

Schumpeter, J. A. (1942): Capitalism, Socialism and Democracy. Harper and Row, NY.

Schumpeter, J. A. (1939): Business Cycles: A Theoretical, Historical and Statistical Analysis of the Capitalist Process. McGraw-Hill, New York.

Shane, S. and Venkataraman, S. (2000): The Promise of Entrepreneurship as a Field of Research, Academy of Management, 25 (1): 217-226.

Shane, S. (2004): A General Theory of Entrepreneurship, Edward Elgar, New York.

Stiglitz, J. B. (2002): Globalization and its Discontent, New York, Norton.

Storey, D. J. and Greene, F. J. (2010): Small Business and Entrepreneurship, Pearson, London.

SARB (2013): South African Reserve Bank Quarterly Bulletin, Pretoria (June).

Sunter, C. (2013): $21^{\text {st }}$ Century Megatreds, Natal Witness, 7 January.

Timmons, J. A. (2007): New Venture Creation, McGrawHill, New York. 
Urban, B. (2008): Frontiers in Entrepreneurship, Heinemann, Sandton.

Van Aardt, I., van Aardt, C., Bezuidenhout, S. and Mumba, M. (2008): Entrepreneurship and New Venture Management, $3^{\text {rd }}$ edition, Oxford University Press, Cape Town.

Van Daalen, H. J. (1992): The Psychology of Third World Entrepreneurship. Paper presented at the fifth annual conference of the International Council for Small Business Southern Africa, Johannesburg, 17-19 May.

Van der Merwe, W. G. (1984): Achievement Motivation and the Entrepreneur. Inaugural lecture delivered at the University of Fort Hare, 7 September.

Wennekers, S. and Thurik, R. (1999): Linking Entrepreneurship and Economic Growth. Small Business Economics, 13 (1): 27-56.

Wickham, P. A. (2005): Strategic Entrepreneurship, Prentice Hall, London. 